\title{
Por que não posso "querer fixar o sol e observar a lua"?: "Desviantes" do trabalho e seu adoecimento na Colônia Juliano Moreira-RJ (1930-1945)
}

\author{
Why can't I "want to fix the sun and observe the moon"?: \\ "Deviants" from work and their falling ill in of the Colônia \\ Juliano Moreira-RJ (1930-1945)
}

\section{Anna Beatriz de Sá Almeida* Ana Carolina de Azevedo Guedes ${ }^{* *}$}

Resumo: Neste artigo, analisamos a história de homens internados na Colônia Juliano Moreira (CJM) que apresentaram indícios em suas documentações de internações de doenças mentais relacionadas com o trabalho. A metodologia de trabalho foi o levantamento e seleção do grupo de internos, analisando as principais fontes documentais: os prontuários dos internos. No Brasil, foi durante o governo Vargas que o trabalho e o trabalhador foram sendo alvos de políticas públicas mais intensas na busca da construção da "nação". Do indivíduo homem, provedor da família e cidadão trabalhador produtivo se esperava que fosse um "respeitável" chefe de família, gozando de boa saúde e muito disciplinado, a base da construção nacional. Assim, qualquer desvio nesse modelo - fosse por indisciplina ou esgotamento físico e mental decorrente das atividades e das condições de trabalho - tornava esses homens "desviantes" do projeto de nação e sociedade que se defendia naquele momento e, portanto, passíveis de serem considerados "loucos" e internados em instituições psiquiátricas para tratamento e recuperação.

Palavras-chave: história da loucura; história do trabalho; história do Brasil.

* Doutora em História pela Universidade Federal Fluminense (UFF), pesquisadora da Casa de Oswaldo Cruz da Fiocruz. ORCID: http://orcid.org/0000-0002-4501-3011. E-mail: almeida.annabeatriz@gmail.com.

** Mestre em História Política pela Universidade do Estado do Rio de Janeiro (UERJ), doutoranda em História Cultural na Pontifícia Universidade Católica do Rio de Janeiro (PUC-RJ). ORCID: https://orcid.org/0000-00022561-3175. E-mail: anaazevedoguedes@gmail.com. 
Abstract: In this article, we analyze the history of men hospitalized in Colônia Juliano (CJM) who presented evidence in their documentation of hospitalizations for work-related mental illnesses. The work methodology was the survey and selection of the group of interns analyzing the main documentary sources of the interns' medical records. In Brazil, it was during the Vargas government that labor and workers became targets of more intense public policies in the search for the construction of the "nation". The individual man, provider of the family and citizen - productive worker, was expected to be a "respectable" head of the family, enjoying good health and very disciplined, the basis of national construction. Thus, any deviation from this model, whether due to indiscipline or physical and mental exhaustion resulting from activities and working conditions, made these men "deviants" from the project of nation and society that was defending themselves at that time and, therefore, liable to be considered "Crazy" and hospitalized in psychiatric institutions for treatment and recovery.

Keywords: History of madness; labour history; history of Brazil.

\section{Introdução}

O DESEJO DE "querer fixar o sol e observar a lua", utilizado no título do nosso artigo, pertencia a Eduardo, ${ }^{1}$ um rapaz de 27 anos, branco, solteiro, operário, brasileiro que foi diagnosticado como psicótico maníaco-depressivo e internado na Colônia Juliano Moreira (CJM) em 1945. De acordo com o médico da instituição que o atendera: "o que mais o preocupa[va] [eram] questões 'planetárias' em querer fixar o sol e observar a lua”. ${ }^{2}$ Já o irmão de Eduardo, presente no momento da internação, afirmara que as primeiras perturbações mentais do irmão iniciaram quando ele sofreu um acidente no trabalho, caindo de um andaime e batendo com a cabeça em uma pedra, havia mais de oito anos. Começou abandonando seus hábitos religiosos, tornando-se cada dia mais relapso no trabalho, chegando a abandoná-lo. Em casa tinha episódios de agitação, falando muito, dançando e, logo depois, entrando em depressão e desânimo. Por sua vez, Eduardo afirmava ter feito uma grande descoberta: vira um avião na lua e merecia um prêmio em dinheiro pelo fato! Foi com base nas observações sobre e do próprio Eduardo que criamos o diálogo fictício no título com o qual se inicia o presente artigo.

Uma das questões norteadoras da pesquisa desenvolvida, ${ }^{3}$ com base na qual resultou este artigo, foi analisar de que forma o universo do trabalho e do não trabalho estiveram

1 Seguindo as instruções do CEP da EPSJV/Fiocruz, os nomes verdadeiros dos internos foram substituídos por codinomes e, ao longo do artigo, não há referências a nomes e/ou endereços de membros da família, do círculo social e nem dos médicos que os atenderam.

2 Caso 22 - Eduardo. Ficha de observação de E.T.Q. CJM, caixa 64, ano 1945. Acervo IMASJM/SMS-RJ.

3 Este artigo é um recorte dentro do projeto de pesquisa: "História e trajetórias de 'internos desviantes': doenças mentais, doenças do trabalho e homossexualismo na Colônia Juliano Moreira, RJ (1930-1945)", coordenado por Anna Beatriz de Sá Almeida, tendo como equipe: Ana Carolina de Azevedo Guedes (pesquisadora auxiliar), Alexia Iduíno (bolsista IC Faperj) e Renata Marinho (bolsista IC CNPq/Fiocruz). O projeto contou com apoio financeiro da Faperj na modalidade APq 1. 
presentes nas histórias de internos da CJM no período de 1930 a 1945. ${ }^{4}$ Buscamos selecionar, nas documentações clínicas dos pacientes homens internados neste período, os casos nos quais as motivações para internação tivessem diferentes formas e intensidades relacionadas com o trabalho. ${ }^{5}$

Com base nessa questão norteadora, analisamos as fontes disponíveis buscando, sempre que possível, reconstruir o universo desses sujeitos que tiveram suas histórias marcadas pelos processos de internação. Ao longo do artigo, numa primeira parte, discutiremos questões relacionadas às temáticas e ao contexto histórico da análise; em uma segunda parte apresentaremos características do grupo de internos; e na terceira parte nos debruçaremos sobre alguns internos, abordando especificidades de muitas dessas trajetórias. Buscaremos apresentar, sempre que possível, suas percepções, suas angústias, desejos e inquietações.

Inicialmente situaremos o espaço onde se dá nosso trabalho. A CJM é uma instituição psiquiátrica fundada sob o nome de Colônia de Psicopatas Homens, em 1924, na região de Jacarepaguá, Rio de Janeiro. Em 1935 ela se amplia e passa a se chamar Colônia Juliano Moreira, funcionando sob o regime de asilo-colônia, onde os internos poderiam gozar de espaço aberto e contato com a natureza, além de ter como terapia o modelo heterofamiliar, onde os funcionários recebiam os internos em suas casas, com o objetivo de integrá-los em um sistema de convivência, visando sua reinserção na sociedade. Cinco anos depois é feita uma nova ampliação física para atender o campo de assistência psiquiátrica nacional, onde a colônia passa a receber internas mulheres no contexto de aumento do atendimento a doentes mentais por parte do governo federal. Segundo Venancio e Potengy:

Em seu caso específico somaram-se às terapias originárias - praxiterapia e assistência heterofamiliar - tratamentos considerados 'modernos' à época, como eletrochoque, as lobotomias, mas também a terapia ocupacional e os ambulatórios de higiene mental. Nos anos 1990, após longo processo de deterioração, iniciou-se sua desativação parcial e sua municipalização, por meio de ações que passaram a ser concretizadas na década de $2000 .^{6}$

Esse processo de ocupação do que ficou conhecido como "sertão carioca"7 passa diretamente pela necessidade de desativação de hospitais que funcionavam no centro da cidade do Rio de Janeiro, além do apartamento desses indivíduos dos espaços sociais. A escolha da construção

$4 \quad$ Desde as últimas décadas do século $\mathrm{XX}$, tem sido crescente o diálogo do campo mundos do trabalho com uma ampla diversidade de temáticas, nas quais se apresentam trabalhos acerca da história da saúde, doença e medicina do trabalho. Cf.: Dossiê temático "Trabalho, saúde e medicina na América Latina" na Revista Mundos do Trabalho, Florianópolis, v. 7, n. 13, jan.-jun. 2015, organizado por Adriano Luiz Duarte e Óscar Gallo, reunindo vários trabalhos abordando questões relativas ao tema.

5 Foram levantadas mais de mil fichas das quais selecionamos 64 casos de internos relacionados ao mundo do trabalho, menos de $10 \%$ do total. Nesse sentido, ressaltamos ser nossa pesquisa do tipo qualitativa, sem ter havido, em momento algum, interesse quantitativo.

6 VENANCIO, Ana Teresa A.; POTENGY, Gisélia Franco. Apresentação. In: VENANCIO; Ana Teresa A.; POTENGY, Gisélia Franco (org.). $\mathbf{O}$ asilo e a cidade: histórias da Colônia Juliano Moreira. Rio de Janeiro: Garamond, 2015. p. 14.

7 Para maiores informações, cf.: POTENGY, Gisélia Franco; HOPPE, Sigrid. Identidade e apropriações do espaço do bairro Colônia. In: VENANCIO; POTENGY (org.), op. cit., p. 273-308. 
da Colônia Juliano Moreira em Jacarepaguá aconteceu diante da doação da freguesia, ainda na década de 1920, e sua localização foi determinante.

Num espaço onde a internação ocorria por recolhimento policial (seja por prisão por vadiagem ou denúncias), por decisão familiar ou mesmo por autointernação, a história da CJM extrapola os limites dos documentos institucionais. Grande parte de sua riqueza está nas fichas de observação e nos prontuários que serão os alvos de nossas análises.

Mesmo sabendo que todas as falas dos internos e de seus familiares passavam pelo crivo dos médicos que anotavam a seu modo as observações e colocações feitas pelos mesmos, acreditamos ser possível chegar no que "contam" esses sujeitos por meio das palavras utilizadas pelo médico, pelo uso de aspas em determinados trechos das observações das consultas, pela descrição física e emocional dos pacientes feita pelos psiquiatras, entre outras várias possibilidades, tais como, bilhetes, desenhos, recortes de jornais etc. anexados à documentação clínica dos mesmos. Nas palavras de Wadi, as pessoas internadas em instituições psiquiátricas:

"contam" sobre tais lugares, ou seja, narram, relatam, referem-se a diferentes aspectos desses lugares e de suas vidas, dentro e fora deles. Nesse sentido, considerando algumas das diversas acepções do verbo contar, suas narrativas tanto podem referir fatos ou acontecimentos vividos quanto supostos ou imaginados. ${ }^{8}$

Existem várias e interessantes historiografias ${ }^{9}$ do campo da história da loucura e da psiquiatria que nos mostram que podemos construir nossas análises com diversos referenciais teóricos. Pelas considerações feitas logo acima, buscamos fazer uma história social da loucura e da psiquiatria, com ênfase especial nos sujeitos tidos como "loucos" e, nesse sentido, passíveis de serem internados em instituições psiquiátricas. Novamente concordaremos com as colocações de Wadi:

Esse olhar dos internos expresso nas narrativas torna possível entrever algo que constantemente escapa a muitos - aos próprios especialistas das diversas ciências, aos psiquiatras e mesmo a alguns historiadores da loucura e da psiquiatria - que acreditam ser a loucura uma totalidade fora da história, constante universal, regularidade a-histórica. Permite compreender que toda experiência, inclusive a da loucura, tem múltiplas dimensões e temporalidades, elementos dispares, lógica incomum, cenas e falas próprias, sendo constituinte de sujeitos. Ao olhar para as experiências particulares, contextualizadas em situações históricas precisas, torna-se possível perceber as "questões de vida" envolvidas em cada história. ${ }^{10}$

8 WADI, Yonissa M. "Entre muros": os loucos contam o hospício. Topoi, Rio de Janeiro, v. 12, n. 22, p. 220-269, jan.- jun. 2011. p. 250.

9 da Fiocruz. ORCID: http://orcid.org/0000-0002-4501-3011. E-mail: almeida.annabeatriz@gmail.com Cf.: VENANCIO, Ana T. A.; CASSILIA, Janis A. P. A doença mental como tema: uma análise dos estudos no Brasil. Revista Espaço Plural, Marechal Cândido Rondon, ano XI, v. 1, n. 22, p. 24-34, jan.-jun. 2010; WADI, Yonissa M.; SANTOS, Nádia M. W. (org.). História e loucura: saberes, práticas e narrativas. Uberlândia: Edufu, 2010.

10 WADI, op. cit., p. 256. 
De acordo com a análise de Charles Rosenberg, ${ }^{11}$ o processo de negociação, de definição e de respostas a uma doença é um processo bastante complexo e que possui inúmeras camadas que incluiriam os elementos cognitivos e disciplinares, as políticas públicas e institucionais e as diferentes maneiras como os indivíduos e seus grupos sociais viveriam tais doenças. $\mathrm{O}$ autor opta pela metáfora "framing disease" como o modo de poder analisar uma determinada doença com um "emolduramento" da sociedade na qual ela se insere culturalmente, biologicamente, politicamente, cientificamente etc. Segundo Rosenberg, “(...) uma vez cristalizada na forma de entidades específicas e vista como existindo em indivíduos particulares, a doença serve como fator estruturante em situações sociais, como ator e mediador social". ${ }^{12}$

Assim, as doenças só seriam passíveis de serem enquadradas e classificadas como uma "doença" dentro do contexto social de cada época, como resultantes de amplos processos das sociedades envolvendo interesses, culturas, saberes e políticas científicas e de saúde em uma ampla rede de negociações, que culminariam pela caracterização das doenças e de seus doentes. Trazendo tais considerações para o universo das doenças mentais - tema do nosso artigo -, podemos perceber parte desse processo analisando a documentação clínica dos internos na qual os médicos da CJM caracterizavam e diagnosticavam seus pacientes como doentes mentais.

Doenças mentais decorrentes do alcoolismo (relacionando o trabalho ao desejo frequente de consumir bebidas alcoólicas), dos acidentes do trabalho, das precárias condições do ambiente de trabalho; do excesso de trabalho, das exigências excessivas de desempenho; das perseguições e alucinações vividas; do medo da demissão e das situações de desemprego prolongado foram encontradas como motivações da internação em nossa análise dos 64 prontuários de homens internos na CJM de 1930 a 1945, ao longo do primeiro governo Vargas. ${ }^{13}$

O primeiro governo Vargas foi marcado por um conjunto de ações (leis, agências etc.) no campo das políticas sociais buscando legitimar o novo Estado e criar o novo cidadão/ trabalhador responsável pelo desenvolvimento e crescimento harmônico da nova nação. Nesse contexto, foram instituídos o Ministério da Educação e da Saúde Pública e o Ministério do Trabalho, Indústria e Comércio, entre outras instituições voltadas para as políticas sociais priorizadas pelo novo governo.

A doutrina do Estado Novo propõe todo o poder necessário ao Estado, visto como única instituição capaz de garantir a coesão nacional e de realizar o bem público, para além dos interesses reais mais mesquinhos dos indivíduos e dos grupos. Desenvolve, também, a crença no homem excepcional, portador de virtú, como o único capaz de expressar e construir a nova ordem. ${ }^{14}$

11 ROSENBERG, C. E. Introduction - Framing Disease: Illness, Society and History. In: ROSENBERG, C.; GOLDEN, J. (org.). Framing Disease. Studies in Cultural History. New Brunswick: Rutgers University Press, 1992. p. XIII-XX.

12 Ibidem, p. XIV. "(...) once crystallized in the form of specific entities and seen as existing in particular individuals, disease serves as a structuring factor in social situations, as a social actor and mediator" (tradução nossa).

13 Acompanhando a produção mais recente no campo, vemos que a maior parte dessas realidades infelizmente continua presente nos mundos do trabalho contemporâneo.

14 OLIVEIRA, Lúcia Lippi. Introdução. In: OLIVEIRA, L. L.; VELLOSO, M. P.; GOMES, A. M. C. Estado Novo: ideologia e poder. Rio de Janeiro: Zahar Editores, 1982. p. 24. 
No conjunto maior da obra de construção do trabalhador nacional e de "revisão moralizadora" do conceito de trabalho, tem espaço e vai sendo construído o campo da medicina do trabalho. Cuidar da saúde do trabalhador nacional e por extensão de sua família é cuidar da nação, do conjunto da nacionalidade,$^{15}$ estabelecendo como parâmetro para essa sociedade a imagem do homem trabalhador, saudável, provedor da família.

Freire, ao analisar a ideologia da maternidade ao longo da década de 1920, ressalta o contexto amplo no qual tal movimento se inseria, o que nos permite compreender o projeto republicano para a construção da nação:

No Brasil, esse fenômeno apresentou dimensão singular associada às especificidades do cenário econômico, político e social, em particular o projeto modernizador republicano que depositava na conservação das crianças entre outros elementos esperança para a viabilidade da nação. ${ }^{16}$

Dessa forma, os trabalhadores vão sendo "diagnosticados no seu dia a dia, clinicados através de dispositivos que permitam a sua regeneração física e moral". ${ }^{17}$ Ao se referir a esse ideal de nação harmônica, na qual o trabalhador saudável era peça primordial, Gomes ressalta:

(...) é dentro desta concepção que o projeto político do Estado Novo é definido: no plano econômico, como a articulação das forças vivas do individualismo, sem qualquer hipertrofia ou esmagamento, e no plano social, como a proteção do trabalho pela harmonização e proteção de todas as classes. ${ }^{18}$

O período de 1930 a 1945 está permeado por profundas mudanças no campo das políticas e das instituições de saúde e, especialmente, em relação à doença mental. Por outro lado, constituía-se o campo da medicina do trabalho no país com estudos relacionando as condições de trabalho e o adoecimento dos trabalhadores; estudos acerca dos acidentes de trabalho; da fadiga; do trabalho das mulheres e dos menores - entre outras temáticas, em um período de grande valorização do trabalho e dos trabalhadores na construção da "nação". Dentro desse contexto também são organizados serviços e normas voltados à saúde e proteção do trabalhador, com destaque às condições de trabalho e aos acidentes e doenças do trabalho. ${ }^{19}$

O artigo de Silva, ao analisar processos de indenização de acidentes e doença do trabalho em determinados grupos de profissionais em Salvador, Bahia, ao longo dos anos de 1930 e 1940, nos aponta uma realidade vivida por inúmeros trabalhadores e trabalhadoras na busca pelos seus direitos quando acidentados ou adoentados pelo trabalho, tendo como base

15 ALMEIDA, Anna Beatriz de Sá. As doenças do "trabalho" no Brasil no contexto das políticas públicas voltadas ao trabalhador (1920-1950). Revista Mundos do Trabalho, Florianópolis, v. 7, n. 13, p. 65-84, jan.-jun. 2015.

16 FREIRE, Maria Martha de Luna. "Ser mãe é uma ciência": mulheres, médicos e a construção da maternidade científica na década de 1920. História, Ciências, Saúde - Manguinhos, Rio de Janeiro, v. 15, supl., p.153171, jun. 2008, p. 154.

17 LENHARO, Alcir. Sacralização da política. São Paulo: Papirus, 1986. p. 100.

18 GOMES, Angela M. de Castro. A invenção do trabalhismo. São Paulo: Vértice; Rio de Janeiro: IUPERJ, 1988. p. 222.

19 ALMEIDA, Anna Beatriz de Sá. As parcelas (in)visíveis da saúde do trabalhador: uma contribuição à história da medicina do trabalho no Brasil (1920-1950). Tese (Doutorado em História) - Universidade Federal Fluminense, Niterói, 2004. 
as Leis de Acidentes de Trabalho de 1919 e de $1934 .{ }^{20}$ Nos casos dos internos que iremos analisar, alguns poucos cujo trabalho tinha vínculo formal chegaram a ser aposentados em função de acidentes e doenças do trabalho. Mas, a maior parte deles, inferimos que - ou por não terem vínculos formais, ou por não terem conhecimento dos seus direitos em função dos acidentes e doenças causadas pelo trabalho - não abriram tais processos, ao menos não localizamos menções aos mesmos em suas documentações. Concordamos plenamente com Silva quando ela aponta em suas considerações finais que:

no momento em que o discurso governamental se colocava como defensor do trabalho e dos trabalhadores, a partir de uma legislação social que os "amparava", a realidade do trabalho sob a ótica de doenças e de acidentes, o desmistificava. Esse discurso não era acompanhado de ações efetivas de fiscalização e de controle dos ambientes de trabalho. ${ }^{21}$

Estivesse o Estado e seus órgãos fiscalizadores mais presentes, não teríamos tantos trabalhadores e trabalhadoras sem vínculos formais, nem mesmo condições e ambientes de trabalho tão degradantes e perigosos à vida e integridade física dos mesmos, os quais eram exaltados como trabalhadores - base da construção da nação e do progresso.

Do indivíduo homem, provedor da família e cidadão - trabalhador produtivo -, se esperava que fosse um "respeitável" chefe de família, gozando de boa saúde e muito disciplinado, um modelo exemplar, na medida em que seriam ele e a sua família a base de construção do país.

(...) os 'distúrbios mentais' seriam diagnosticados de forma mais significativa em homens que se recusavam ou não conseguiam cumprir os papéis sociais de trabalhador e provedor ou, ainda, sofriam as implicações negativas do seu desempenho. ${ }^{22}$

Dessa forma, qualquer desvio nesse modelo de homem trabalhador saudável caracterizaria os mesmos como homens "desviantes" do projeto de nação e do desenho de sociedade existente e, portanto, passíveis de serem considerados "loucos" e internados em instituições psiquiátricas para tratamento e recuperação. Passaremos agora a apresentar características do nosso universo de internos da CJM.

\section{Características sociais e de saúde dos internos}

As FICHAS DE OBSERVAÇÃo dos internos da CJM constavam basicamente de uma folha de rosto padrão com diversas questões como: nome, filiação, endereço, data de nascimento, idade, cor, situação civil, escolaridade, profissão, procedência e situação financeira de

20 SILVA, Maria Elisa Lemos Nunes da. Entre lançadeiras, guindastes e trilhos: doenças e acidentes de trabalho em Salvador nas décadas de 1930 e 1940. Revista Mundos do Trabalho, Florianópolis, v. 7, n. 13, p. 215231, jan.-jun. 2015.

21 Ibidem, p. 230.

22 ENGEL, Magali Gouveia. Sexualidades interditadas: loucura e gênero masculino. História, Ciências, Saúde - Manguinhos, Rio de Janeiro, v. 15, supl., p. 173-190, jun. 2008. p. 174. 
maneira geral. Muito raramente todas estas questões eram completamente preenchidas, mas, muitas vezes, ao longo das consultas com os psiquiatras, algumas respostas apareciam. $\mathrm{Na}$ anamnese feita com os pacientes, os médicos seguiam uma espécie de roteiro no qual buscavam extrair informações sobre os antepassados dos internos, acerca do seu parto, das doenças infantojuvenis do mesmo, dos seus hábitos e experiências sexuais, com destaque para a existência de doenças nessa área, com destaque para a sífilis, entre outras.

Com relação à sífilis, as referências à mesma apareceram em vários dos prontuários por nós analisados, bem como era comum que os médicos solicitassem a realização de exames para sífilis a quase todos os internos. Não nos surpreendemos, na medida em que era uma doença bastante presente entre os brasileiros, como bem destacou Carrara em seu estudo sobre a doença nos fins do século XIX até os anos de 1940:

(...) sempre presente no discurso sifilográfico, a equação brasileiro = sifilíitico justificou até mesmo que as estatísticas fossem em certos momentos consideradas dispensáveis ou desnecessárias, quando se tratava de determinar a real extensão da doença no Brasil. ${ }^{23}$

Uma outra situação, comum em vários dos casos analisados, era o comparecimento de parentes dos internos na CJM. A presença de algum familiar no momento da internação, durante a anamnese do interno ou quando realizavam visitas, possibilitavam aos médicos obter mais informações sobre o interno bem como acerca do seu processo de adoecimento. ${ }^{24}$ Apresentaremos a seguir alguns gráficos com algumas características sociais dos internos, bem como os diagnósticos recebidos pelos médicos da CJM.

\section{Gráfico 1 - Faixa etária dos internos}

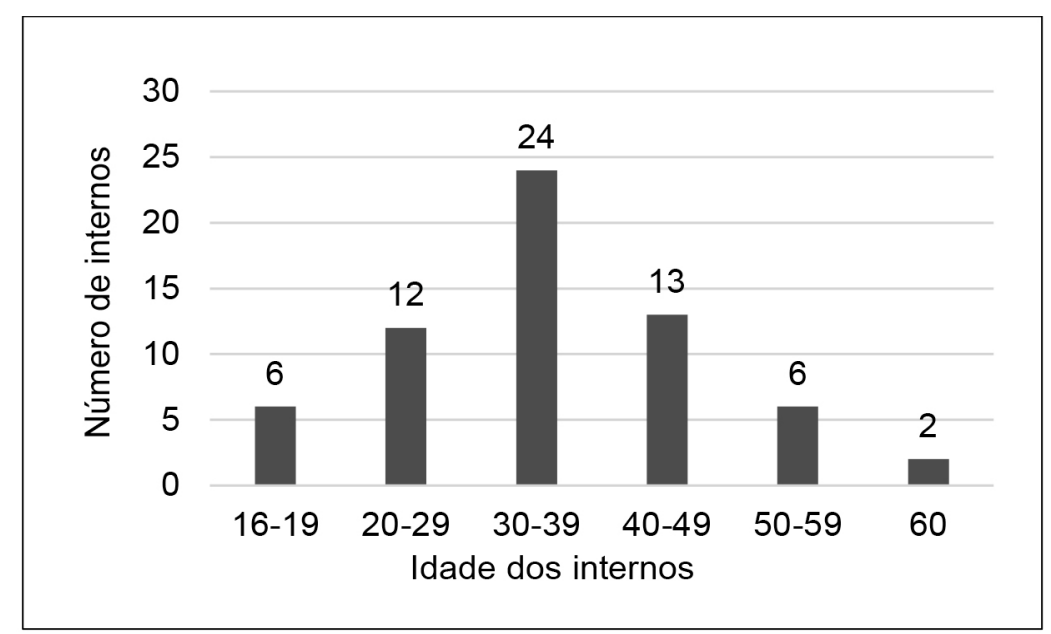

Fonte: Acervo da CJM. IMASJM/SMS-RJ.

23 CARRARA, Sérgio. Tributo a vênus: a luta contra a sífilis no Brasil, da passagem do século aos anos 40 . Rio de Janeiro: Editora Fiocruz, 1996. p. 114.

24 A base dos internos desviantes do trabalho seguiu o modelo originalmente criado pela pesquisadora Cristiana Facchinetti (COC/Fiocruz). 
Como podemos observar, mais de $50 \%$ dos internos se encontravam no auge da idade laborativa, tendo entre 20 e 49 anos, momento da vida em que a "nação" contava com seus trabalhadores saudáveis e provedores. Era importante, portanto, que a instituição buscasse devolvê-los à sociedade, de forma que os mesmos retornassem ao mercado de trabalho. Mas também foram internados homens de grupos etários mais velhos, bem como de jovens com menos de 20 anos, como o caso que apresentamos a seguir de um jovem de 16 anos.

Jovenal, 16 anos, pardo, solteiro, trocador de ônibus, brasileiro, foi internado em abril de 1939 com o diagnóstico de esquizofrenia, recebendo alta em julho de 1940. Sobre a doença que o levou à internação, nos conta:

Era trocador de uma companhia de ônibus; certa vez, como se estivesse perseguido pelos colegas e pelos espíritos maus, começou a ficar excitado, excitação esta que atingiu o grau máximo de agitação psicomotora. Nesta crise brigou, rasgou seu costume profissional etc. ${ }^{25}$

\section{Gráfico 2 - Cor dos internos}

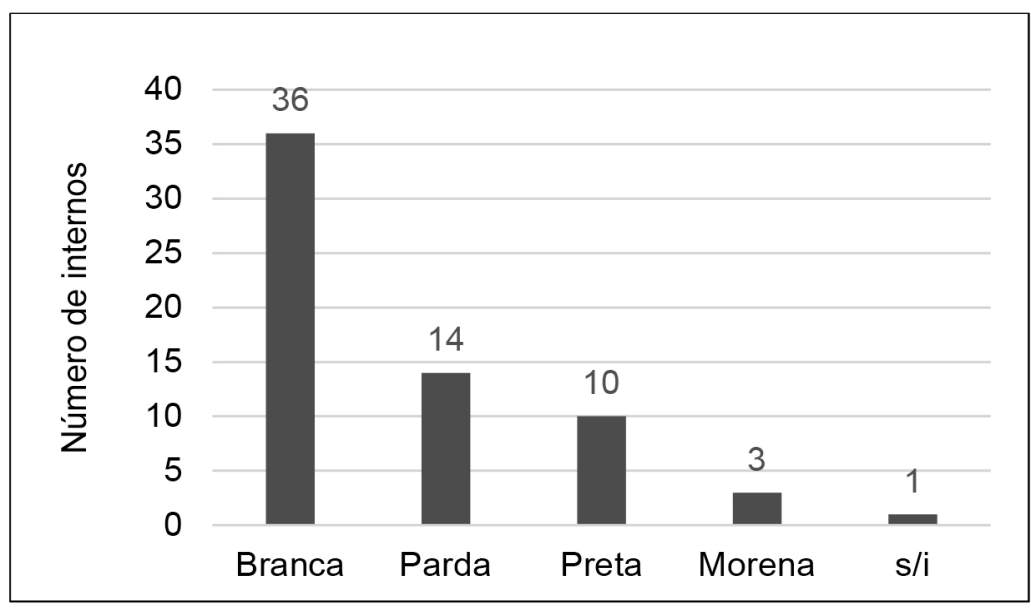

Fonte: Acervo da CJM. IMASJM/SMS-RJ.

O item cor dos internos seguiu as expressões utilizadas na documentação, onde os não brancos seriam definidos como pardos, pretos ou morenos, e também apareceram alguns casos de designação na ficha como moreno e, na avaliação médica, o interno ser considerado pelos médicos como sendo preto e não moreno, ou o inverso; da mesma forma que pardos foram avaliados pelos mesmos como brancos, ou o inverso. Optamos por usar as terminações indicadas pelos médicos no momento das consultas, pois muitas fichas eram preenchidas pela recepção da instituição, de forma inconsistente. Dessa forma, podemos observar que mais de $50 \%$ dos internos foram considerados de cor branca.

O gráfico a seguir, com o tempo de permanência na CJM, dialoga diretamente com os dados anteriores da faixa etária, na medida em que quase a metade dos internos deixou a instituição com menos de um ano de internação, fosse por alta, por evasão ou por morte.

25 Caso 35 - Jovenal. Ficha de observação de J.B.O. CJM, caixa 31, ano 1939. Acervo IMASJM/SMS-RJ. 


\section{Gráfico 3 - Tempo de internação na CJM}

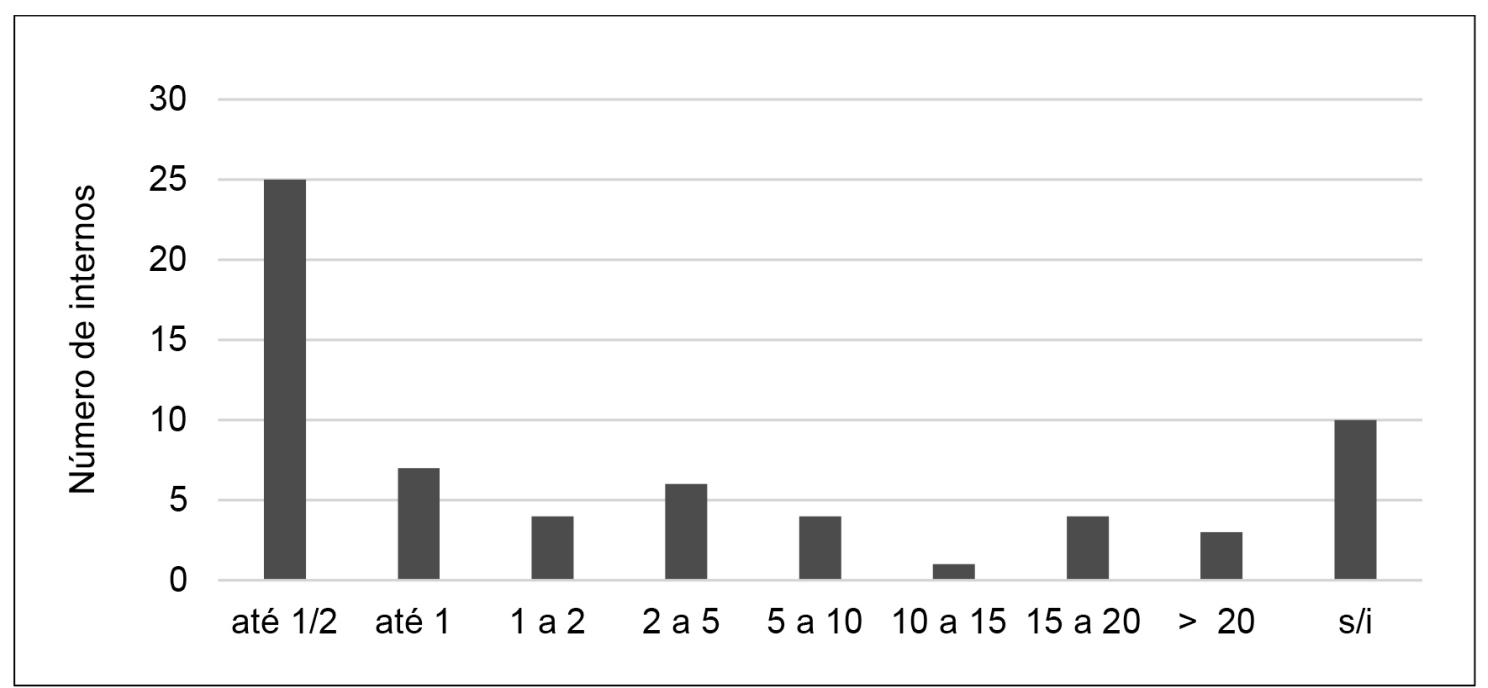

Fonte: Acervo da CJM. IMASJM/SMS-RJ.

Do grupo que faleceu na instituição, localizamos o sr. Antero, que foi internado aos 52 anos, em 1938, casado, trabalhador na limpeza pública e português, o qual, dois meses após a sua entrada, faleceria por insuficiência cardiorrrenal. ${ }^{26}$

Um outro caso, agora de evasão, em menos de um ano, foi o sr. Mauro, 46 anos, pardo, solteiro, brasileiro, trabalhador do Jockey Club, internado em 6/9/1932, evadiu-se quatro meses após sua entrada. ${ }^{27} \mathrm{Um}$ caso de alta experimental sem retorno, o sr. Djalma, 43 anos, branco, separado, português, garçom, deu entrada na CJM em 21/5/1944 e recebeu alta experimental em agosto do mesmo ano. ${ }^{28}$

No grupo dos que permaneceram internados por mais de 20 anos encontra-se o sr. Silvério, 33 anos, casado, operário têxtil, nascido no Distrito Federal, foi internado em janeiro de 1935, diagnosticado como esquizofrênico. Ao contar sua história, destacou: "adoeci com fraqueza por excesso de serviço. Comecei a escarrar sangue - pneumonia -, estava trabalhando demais". ${ }^{29}$ Entre alta a pedido da família, evasões e retornos, permaneceu no mínimo 22 anos internado na CJM. Em uma das suas consultas, relatou ao médico que "fazia muita extravagância - ia para o sol, e o médico disse que eu não podia apanhar sol -, tenho uma agulha dentro da cabeça" ${ }^{30} \mathrm{O}$ médico que o consultava reagiu dizendo ser uma ideia falsa que não deveria ser exposta. Em sua documentação não consta data de alta, evasão ou falecimento após o ano de 1957, de forma que ele pode ter ficado mais do que 22 anos internado na CJM.

26 Caso 4 - Antero. Ficha de observação de A.G.A. CJM, caixa 26, ano 1938. Acervo IMASJM/SMS-RJ.

27 Caso 49 - Mauro. Ficha de observação de M.R.D. CJM, caixa 10, ano 1932. Acervo IMASJM/SMS-RJ.

28 Caso 16 - Djalma. Ficha de observação de D.J.P. CJM, caixa 59, ano 1944. Acervo IMASJM/SMS-RJ.

29 Caso 63 - Silvério. Ficha de observação de S.S. CJM, caixa 17, ano 1935. Acervo IMASJM/SMS-RJ.

30 Ibidem. 


\section{Gráfico 4 - Causas do falecimento dos internos}

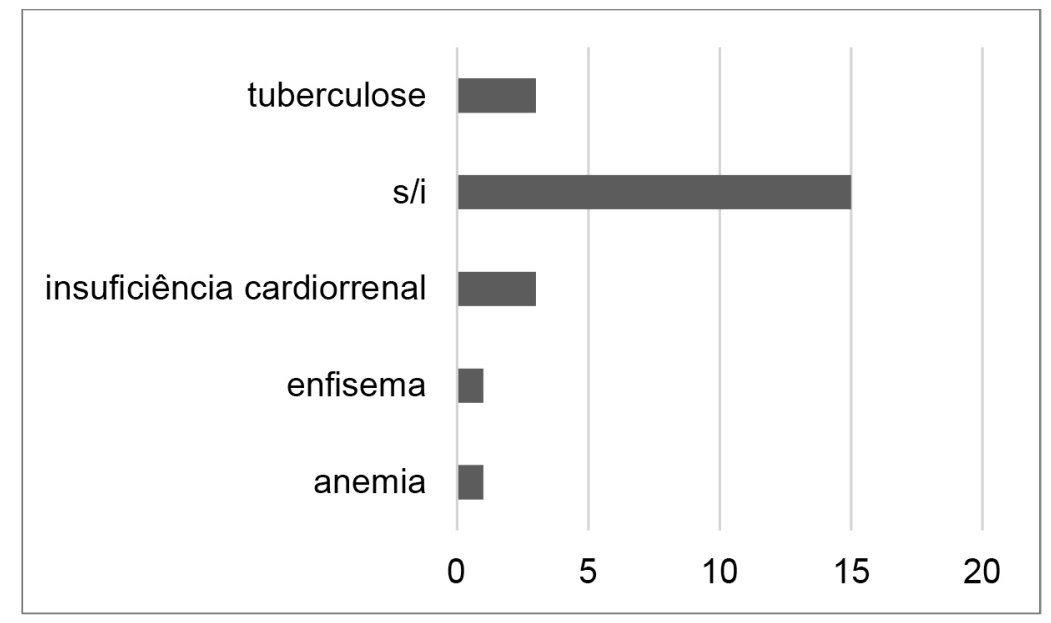

Fonte: Acervo da CJM. IMASJM/SMS-RJ.

No gráfico acima temos os 23 internos do grupo pesquisado que faleceram na CJM e a causa mortis. Entre as doenças que foram apontadas em suas documentações apareceu a insuficiência cardiorrenal que acometeu três internos que estavam internados havia 36 anos, 25 anos e 1 ano na CJM. Os casos de tuberculose ocorreram em internos com menos de três meses na CJM. As doenças enfisema pulmonar e anemia foram as indicadas em um caso de interno com 23 anos de instituição e outro com três anos e meio na CJM, respectivamente. $O$ dado que mais nos surpreendeu foram os 15 internos que não tiveram a causa da sua morte identificada. Nesse grupo, sete tinham menos de 10 anos de internados, um deles tinha 22 anos na CJM, outro tinha 18 anos internado, um outro, 17 anos internado e um último com 11 anos vivendo na instituição.

O que ocorreu? Esquecimento de preencher as fichas antes de arquivá-las junto com as histórias de vida daqueles homens? Eram as doenças desconhecidas? Foram casos que não eram para ser divulgados? Essas questões infelizmente ficaram sem respostas, apenas com vazios e suposições...

Um outro campo de informação bastante relevante é o da profissão dos internos. Em função da grande variedade de profissões apresentadas, optamos por um gráfico com as profissões comuns ao menos a dois internos. No gráfico consta a referência a "outras" profissões, reunindo em torno de 20 atividades que foram listadas em um quadro abaixo do gráfico. Essas foram profissões indicadas por apenas um dos internos e seria inviável inserir todas elas no gráfico de profissões. 


\section{Gráfico $5-$ N. ${ }^{\circ}$ de internos por profissão}

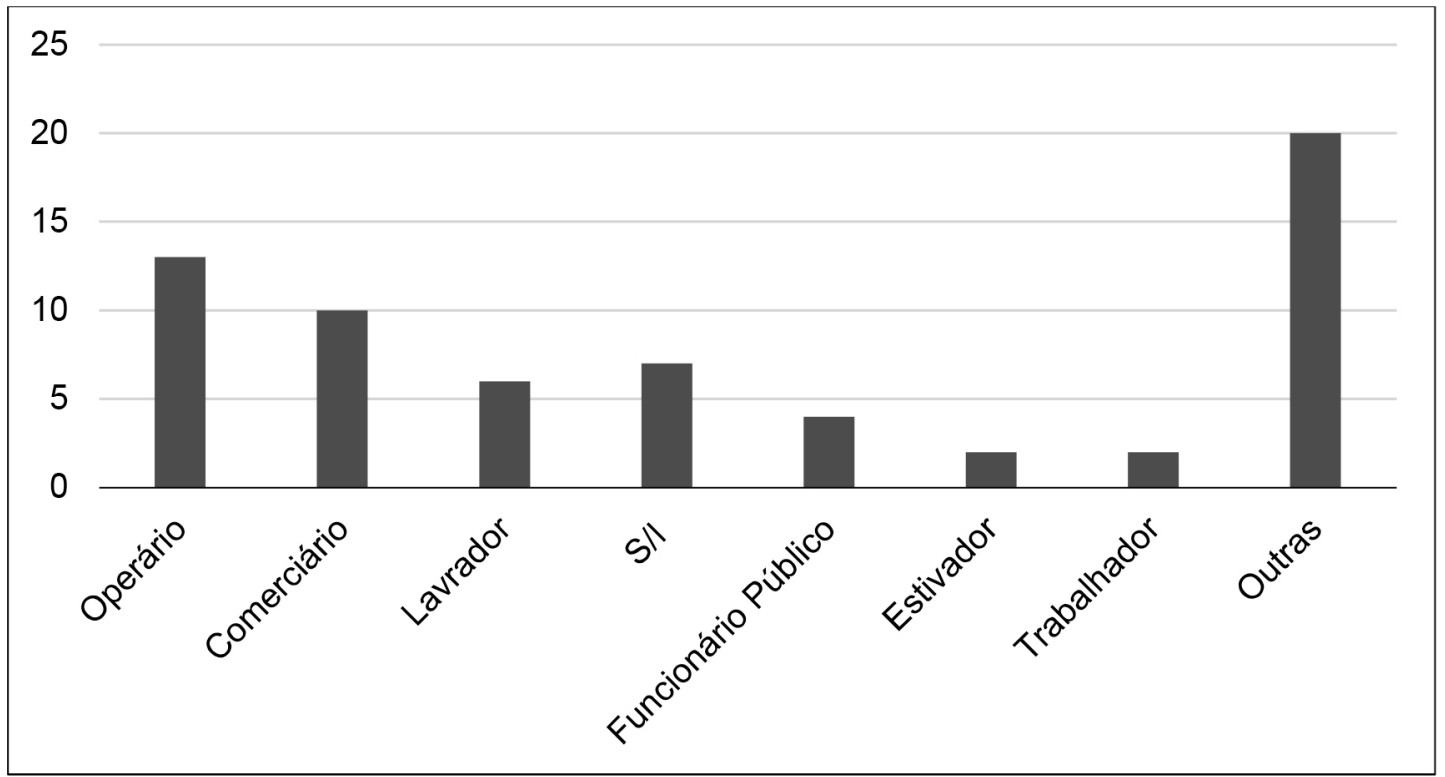

Fonte: Acervo da CJM. IMASJM/SMS-RJ.

Outras profissões: ajudante, aposentado da Light, aprendiz de tipógrafo, calafate, chaffeur, comércio/guarda-livros, contador, entalhador, ferreiro, foguista e músico, garçom, marítimo, mecânico, militar, músico, pedreiro, servente/garçom, tintureiro, trocador de ônibus e vendedor de doces.

S/l: sem informação na documentação dos internos.

Entre as profissões que mais aparecem entre os internos, destacam-se: operário, comerciário e lavrador. Cabe ressaltar ser esse um tipo de dado que em algumas documentações clínicas aparece algumas vezes agrupando duas profissões, dado mantido por nós; ou como em outros casos são informadas profissões diferentes em documentos do mesmo interno, as quais foram incluídas no item outras ou no item sem informação, a depender do caso.

Horácio, 54 anos, viúvo, branco, operário, de origem alemã, ingressou por vontade própria na CJM em outubro de 1945, recebeu o diagnóstico de psicose exotóxica. Em abril de 1962, aos 71 anos, faleceu na CJM que foi seu espaço de vida por 17 anos; trabalhou no apiário como praxiterapia. Nas observações médicas consta o seguinte histórico:

Declara sentir-se fraco e incapaz de poder trabalhar por ter sofrido um acidente (uma punhalada no serviço dada por um companheiro de trabalho na oficina) e ter sido operado no Pronto Socorro, razão do seu apoucamento da sua capacidade de trabalho. Ante essa situação tem feito uso de bebidas alcoólicas, mas se sentido cada vez pior recorre ao tratamento nestes serviços. ${ }^{31}$

Esse caso do sr. Horácio nos sugere que o mesmo por ser viúvo e não ter tido apoio do empregador em função do acidente de trabalho, nem mesmo ter recorrido à indenização por acidente de trabalho, em seu desespero, deva ter visto a CJM como uma opção de local para viver.

31 Caso 30 - Horácio. Ficha de observação de H.A.M. CJM, caixa 64, ano 1945. Acervo IMASJM/SMS-RJ. 
Mário, 24 anos, solteiro, português, era comerciante. Ingressou na CJM trazido por um familiar em janeiro de 1939, quando recebeu o diagnóstico de esquizofrenia paranoide, tendo alta em abril do mesmo ano. De acordo com as informações do parente durante a consulta:

Há mais ou menos um mês - "por perturbação oriunda das responsabilidades da direção de um varejo de cigarros" -, o paciente começou a mostrar-se perturbado, não dizendo as coisas certas, errava nos trocos, dava sempre a marca diferente do que pedissem, passou a dizer-se possuído de um poder superior que diz exercer sobre a atmosfera, as árvores etc. Passava às vezes longo tempo sem falar, comunicando-se somente com gestos. ${ }^{32}$

Um exemplo de lavrador foi o sr. Élcio, 30 anos, pardo, solteiro, deu entrada na CJM em abril de 1937, tendo recebido o diagnóstico de psicótico. Em sua documentação não temos informações sobre sua saída da instituição. Durante a consulta com o médico, ele deu as seguintes informações acerca do seu estado de saúde:

Há muito tempo que se vê amarelo e sofre de coceiras, mesmo nos exercícios moderados. Apresentando o fenômeno da picada, ingestão de terra (...). Sua função em seu meio era o de trabalhador rural de enxada. Seu patrão é que o fez recolher-se a este serviço, segundo declarou. ${ }^{33}$

\section{Gráfico 6 - Diagnóstico dos internos}

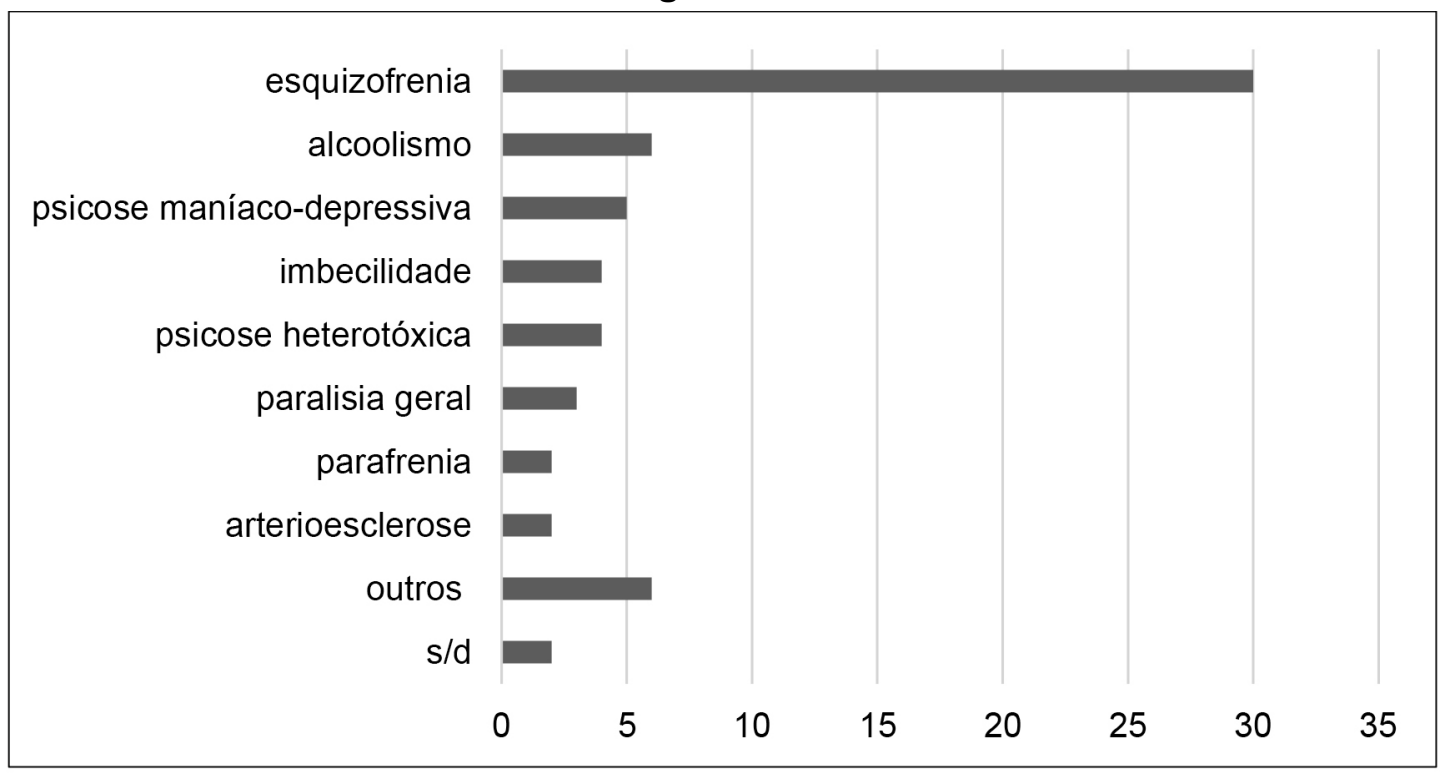

Fonte: Acervo da CJM. IMASJM/SMS-RJ.

No gráfico acima podemos ver que os três principais diagnósticos recebidos pelos internos foram a esquizofrenia, o alcoolismo e a psicose maníaco-depressiva. Destaque-se que o diagnóstico de esquizofrenia foi dado a quase $50 \%$ dos internos. Nesse grupo encontramos Roberto, 26 anos, branco, solteiro, brasileiro, cuja histórico da esquizofrenia, segundo as observações médicas e do interno, deveu-se ao seguinte episódio:

32 Caso 44 - Mário. Ficha de observação de M.S. CJM, caixa 33, ano 1939. Acervo IMASJM/SMS-RJ.

33 Caso 23 - Élcio. Ficha de observação de E.J.S. CJM, caixa 23, ano 1937. Acervo IMASJM/SMS-RJ. 
O paciente diz que trabalhava numa olaria e que o patrão lhe tinha prometido uma carteira de Chaffeur, mas, em tempo, viu que o estava enganando, ficou agitado, andando e falando muito (...). Quando soube do engano em que estava, sentiu a cabeça tonta e agitou-se. ${ }^{34}$

Com relação ao grande número de diagnosticados como alcoólatras, torna-se bastante esclarecedor e importante o estudo de Liane Maria Bertucci que, em trabalho mais amplo acerca da questão da saúde entre os operários paulistas nas primeiras décadas do século $\mathrm{XX}$, analisou o alcoolismo como uma das questões de "ameaça permanente" ao trabalhador:

Indivíduo/coletividade, a questão do alcoolismo aparece em vários artigos da imprensa como uma catástrofe paralelamente pessoal e da comunidade. Problema cuja solução implica na necessidade de alteração do dia a dia das pessoas e, com esta, em mudanças na configuração geral da sociedade. A questão ao alcoolismo coloca-se pois como emblema de uma vida arruinada, gerada por um tecido social doente - aquele em que se desenvolveu a cidade industrial do início do século $\mathrm{XX} .^{35}$

Um caso de internação por alcoolismo é o do sr. Aluísio, 46 anos, branco, solteiro, português, ajudante de cozinha, cujo ingresso deu-se por vontade própria em 10/9/1943, tendo recebido alta após um ano. Segundo as observações médicas e do interno:

sempre trabalhou como ajudante de cozinha ou garçom em botequins. Daí os seus hábitos etilistas antigos [desde 16 anos] e inveterados, embriagando-se por diversas vezes (...). Conta-nos que há três meses principiou a escutar a rádio, dia e noite, dizendo palavras ofensivas e, por isso, ficou perturbado, resolvendo pedir uma guia ao Distrito Policial a fim de ser internado. ${ }^{36}$

O diagnóstico de psicose maníaco-depressiva foi dado ao sr. Pereira, 26 anos, branco, lavrador, brasileiro, internado em 5/12/1934, que após três meses recebeu uma licença da qual não retornou. Segundo as observações clínicas e do interno:

Há onze dias [estava] afastado do trabalho, pelo fato de ter se sentido perturbado das "ideias", acha-se muito nervoso, escuta diariamente "benditos e cantos de Jesus Sacramento", que [atribuía] virem dos astros. Outras tantas vezes, quando no trabalho, punha-se a cantar, mostrando-se noutra ocasião triste, tendo vontade de chorar. ${ }^{37}$

\section{Os internos e os motivos/histórias de suas internações}

OGRÁFICOQUEAPRESENTAREMOSaseguiragrupaosinternos deacordocomaprincipal motivação das suas internações as quais estavam relacionadas ao universo do trabalho, questão por nós abordada na apresentação deste artigo como função primordial do homem trabalhador saudável, cidadão responsável em prover suas famílias em prol da construção de uma nação rica e próspera.

34 Caso 61 - Roberto. Ficha de observação de R.A.S. CJM, caixa 16, ano 1934. Acervo IMASJM/SMS-RJ.

35 BERTUCCI, Liane Maria. Saúde: arma revolucionária. São Paulo - 1891-1925. Campinas: Área de Publicações CMU/Unicamp,1997. p. 81.

36 Caso 5 - Aluísio. Ficha de observação de A.J.R. CJM, caixa 49, ano 1943. Acervo IMASJM/SMS-RJ.

37 Caso 57 - Pereira. Ficha de observação de P.H.S. CJM, caixa 16, ano 1934. Acervo IMASJM/SMS-RJ. 


\section{Gráfico 7 - Número de casos por motivo da internação}

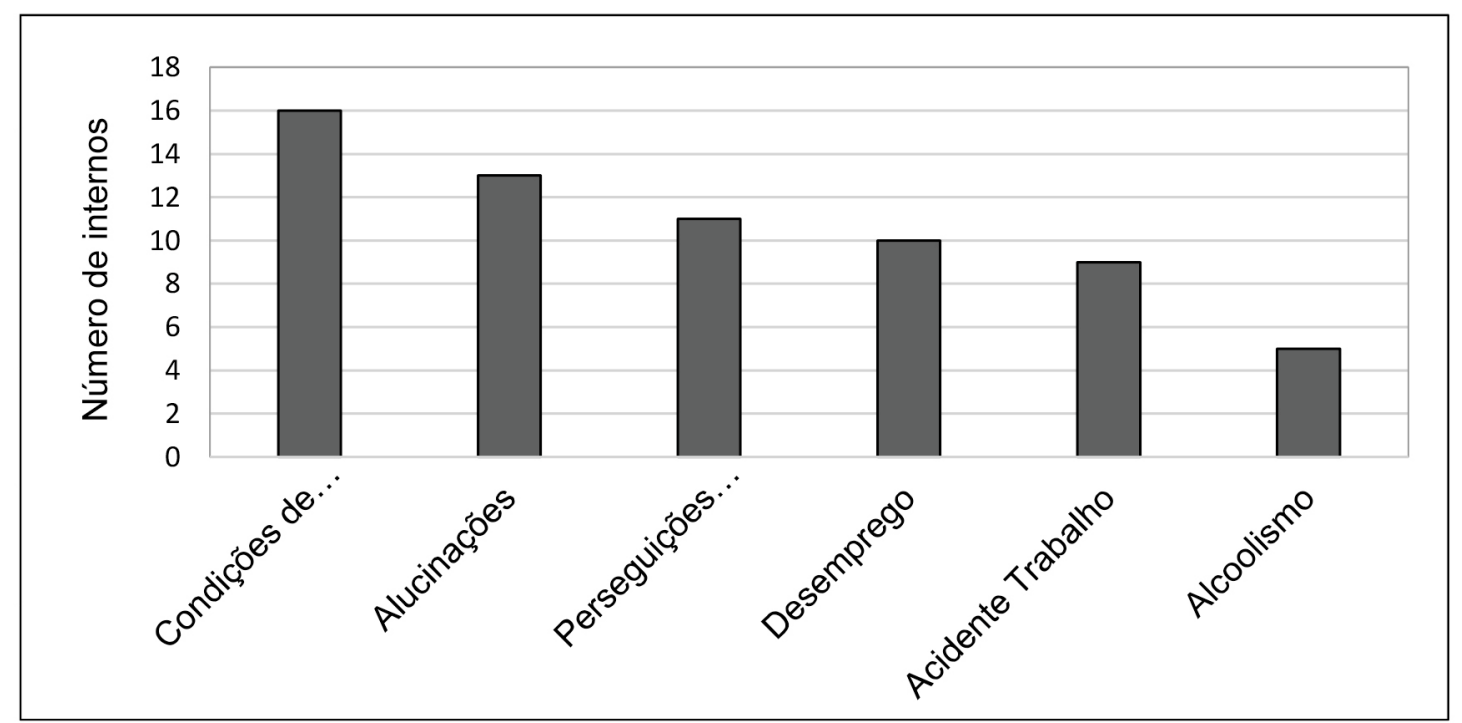

Fonte: Acervo da CJM. IMASJM/SMS-RJ.

Analisando as documentações dos 64 internos, localizamos em suas histórias acerca dos seus problemas mentais, quer contadas pelo próprio, quer por algum familiar, referências às condições e meios nos quais exerciam seus trabalhos, grupo com maior número de casos e que será objeto de análise mais à frente. Os muitos casos relatando processos de alucinações no ambiente de trabalho - como de perseguições sofridas pelos mesmos advindas de colegas ou chefes, levando-os ao total descontrole, ao desemprego e ao desespero nas buscas sem sucesso por empregos -, os acidentes de trabalho ocasionando problemas de saúde e ao alcoolismo, como realidade que os impediu, ao passar do tempo, de exercer suas funções, passaremos a apresentar a seguir algumas das histórias vividas por esses internos.

\section{Histórias de internos e suas alucinações}

Os INTERNADOS em função de apresentarem alucinações relacionadas ao universo do trabalho foram em sua maioria diagnosticados como esquizofrênicos. Alguns receberam alta ou evadiram-se em poucos meses e outros permaneceram internos por mais tempo, tendo havido três casos de falecimento na CJM.

Jairo, 21 anos, moreno, solteiro, brasileiro, ingressou na CJM em fevereiro de 1939, foi diagnosticado como esquizofrênico e evadiu-se sete meses depois. A mãe participou da primeira consulta e é quem dialoga com o médico, pois seu filho apresentava mutismo. Ao falar sobre o aparecimento da doença, ela conta a história do filho:

Relaciona a sua genitora o aparecimento da sua doença a um traumatismo moral. Conta-nos que Jairo escrevera ao presidente da República, solicitando um emprego, que o presidente mandara-o com uma carta ao ministro da 
Fazenda; que um oficial do gabinete apresentou-o àquele ministro, que (...) recebeu-o e mandou que se apresentasse no dia seguinte..$^{38}$

Jairo, diante desses fatos, chegou em casa e teve um "verdadeiro acesso de alegria (satisfação), chegando a arrancar um pivot (...)". Desde então, conta a mãe ao médico, que ele nunca mais voltou ao seu normal e que isto ocorrera havia cinco meses.

Informa a genitora que então notou como perturbações da inteligência de Jairo, mostrar-se este esquecido e abobalhado, ou por vezes muito expansivo [dizia que seria presidente da República] e outras vezes a falar em inglês com Allan Kardec (...). ${ }^{39}$

O interno Melquíades, 33 anos, solteiro, moreno, guarda-civil, piauiense, foi internado na CJM por seu irmão em dezembro de 1943. Conta o irmão que após Melquíades ter solicitado três licenças seguidas do serviço por mostrar-se muito nervoso e esgotado, teve início as manifestações do seu adoecimento:

Informa o acompanhante que o paciente a 22 [de dezembro] arrancou as ligações (fios) das instalações elétricas da casa dizendo que eram cobras e os trincos das portas e os pregos da parede (...). [Levou] todos os objetos para o seu quarto, estendeu um lençol no meio do quarto e proibiu que alguém se aproximasse 'por ser aquela a fronteira'. O paciente apresenta também delírio de interpretação (com os judeus) e de perseguição (a polícia o está perseguindo). ${ }^{40}$

Após receber tratamento, Melquíades recebeu alta da CJM passados três meses da internação.

\section{Histórias de internos que sofriam perseguição no ambiente de trabalho}

EMílıO, 26 ANOS, moreno, solteiro, músico e cearense. Ingressou na CJM em agosto de 1942 quando foi diagnosticado como esquizofrênico, tendo recebido alta dois meses depois. Em sua consulta, o paciente contou ser músico e ter ficado preso por nove meses como comunista extremista. Observa o médico que: "[em suas] ideias delirantes, vê-se como artista de Hollywood e [que fora] impedido pela polícia de assinar contrato com Orson Welles". ${ }^{41}$ Prosseguiu contando ao médico que escuta vozes, sente-se nervoso, esgotado e deprimido e desconfia estar sendo perseguido:

Em consequência da tensão interna criada pelo delírio e desvio de humor, tem frequentemente mudado de serviço, acabando sempre por entrar em conflito com supostos perseguidores em cada local de trabalho. ${ }^{42}$

Nélio, 31 anos, branco, solteiro, paulista, escrivão. Seu ingresso na CJM foi em maio de 1935, tendo falecido após quatro anos, aos 39 anos de idade, sem ter sua causa mortis informada.

38 Caso 32 - Jairo. Ficha de observação de J.C.N. CJM, caixa 31, ano 1939. Acervo IMASJM/SMS-RJ.

39 Ibidem.

40 Caso 46 - Melquiades. Ficha de observação de M.F.L.N. CJM, caixa 54, ano 1943. Acervo IMASJM/SMS-RJ.

41 Caso 20 - Emílio. Ficha de observação de E.C.L. CJM, caixa 43, ano de 1942. Acervo IMASJM/SMS-RJ.

42 Ibidem. 
Acompanhado de um parente ao ingressar na colônia, o mesmo fez questão de frisar ter começado a trabalhar aos 13 anos, se portando sempre de modo sério, pontual e estudioso, só tendo parado suas atividades em função da doença que o trouxe à CJM.

Aparece sua doença quando completou os seus 24 anos de vida. Começou dizendo que, no escritório, onde trabalhava, os companheiros procuravam indispô-lo com o patrão (...) que [ele] o fazia no cumprimento de suas obrigações, redobrando seus esforços, chegando mesmo ao trabalho antes da hora natural do início deste. 'Era uma mania de perseguição', informa (...). Diz-nos que há muito tempo não trabalha, vivendo indolentemente em casas de parentes. (...) Declara-se satisfeito aqui, de onde não quer retirar-se..$^{43}$

Nélio demonstrou estar feliz por passar a "morar" na colônia, recebeu indicação de praxiterapia mas não sabemos da sua história a partir daí, somente da morte ocorrida quatro anos depois. Ele recebeu, em novembro de 1937, 30 dias de licença, da qual retornou em quatro dias. Realmente não tinha vontade de viver fora da CJM.

\section{História de um interno adoecido por não ter emprego}

JURANDIR, 18 ANOS, pardo, solteiro, nascido no Distrito Federal. Teve sua internação requerida pelo pai e entrou na CJM em 22 de dezembro de 1945. Foi diagnosticado com esquizofrenia e, depois de muitas evasões, foi dado como falecido em abril de 1947, aos 20 anos, sem causa informada. Pelas observações do médico, era bastante lento na associação de ideias, apresentando alucinações e nível intelectual bastante deficiente.

Jurandir se apresenta em atitude de grande abatimento, respondendo-nos em voz monótona, como se estivesse em uma ladainha. Trabalhava como ciclista numa padaria, mas tendo sido atropelado por um automóvel, resolveu trabalhar na casa de um almirante, não tendo se dado bem. (...) Foi seu pai quem providenciou sua remoção para cá. Enquanto fala, correm-lhe as lágrimas dos olhos, conservando a cabeça baixa. ${ }^{44}$

Suas características psíquicas físicas e intelectuais não faziam de Jurandir um trabalhador apto, saudável e robusto, o perfil do filho desejado por aquele pai e pelo Brasil para ser um dos trabalhadores construtores da nação. Infiro que a cada evasão ia para casa e o pai o trazia de volta. Resta-nos suas lágrimas e o silêncio acerca da sua morte.

\section{Histórias de internos e seus acidentes de trabalho}

OS CASOS DE INTERNOS relacionados com acidentes de trabalho não guardam aspectos em comum nos itens diagnóstico, tempo de internação e forma de saída da CJM, por exemplo. Passaremos a apresentar dois casos selecionados.

43 Caso 50 - Nélio. Ficha de observação de N.B. CJM, caixa 18, ano de 1935. Acervo IMASJM/SMS-RJ.

44 Caso 37 - Jurandir. Ficha de observação de J.B. CJM, caixa 64, ano de 1945. Acervo IMASJM/SMS-RJ. 
Baltazar, 20 anos, pardo, solteiro, paraibano. Ingressa em dezembro de 1938, recebe o diagnóstico de esquizofrenia e passa 36 anos internados na CJM, até o dia em que faleceu de insuficiência cardiorrenal aos 56 anos. Serviu na Marinha e foi julgado inválido em função de um acidente, sendo asilado com pensão. Reproduzo a seguir um pouco das informações da sua ficha de observação:

Não sabe informar a razão e estar aqui [não se recorda do acidente]. Exame psíquico: paciente calmo, calado quando abandonado a si (...). Gestos e mímicas reduzidas. Desorientado no tempo e no meio. Associação de ideias lenta. Memória enfraquecida. Parece ter alucinações auditivas. Idealização pobre. Afetividade e iniciativa abaladas. Raciocínio e julgamento falhos. ${ }^{45}$

Participou de várias funções na praxiterapia: auxiliar de conservação, auxiliar de roça e servente, tendo passado dos 20 aos 56 anos interno na CJM.

Euclides, 33 anos, branco, solteiro, condutor de trem, nascido no Distrito Federal. Deu entrada na CJM em junho de 1942 e evadiu-se dois meses depois. A irmã que o acompanhava disse que o irmão já estivera internado no Instituto de Neuro-Sífilis, quando foi diagnosticado e tratado da sífilis que já o comprometia.

Contou-nos a irmã que o paciente era agente da Leopoldina, quando em 1938 [quatro anos atrás] sofreu um abalo nervoso por ter ocasionado um encontro de trens, provavelmente pela própria doença (...). Foi aposentado visto ter sido julgado inválido definitivamente. ${ }^{46}$

Continuou a irmã contando que, nas últimas semanas, Euclides estava falando em demasia sobre a necessidade de voltar a trabalhar e então foi necessário trazê-lo para a CJM. O médico anotou em suas observações que o paciente não tinha noção da sua doença no sistema nervoso e julgava-se perfeitamente bem para voltar ao trabalho, sem lembrar-se nem do acidente, nem da aposentadoria.

\section{Histórias de internos alcoólatras em função do trabalho}

OS CASOS EM QUE o alcoolismo foi associado ao ambiente ou às condições de trabalho nos trazem algumas características interessantes. Entre os cinco casos classificados por nós como alcoolismo em função do trabalho, três internos receberam alta em pouco tempo, enquanto os outros dois faleceram na CJM. Desses internos, três ingressaram de forma voluntária.

Vamos apresentar um pouco da história do sr. Eliomar, 52 anos, branco, solteiro, nascido no interior do estado do RJ, entalhador.

Apresenta-se emagrecido, fisionomia flácida, cansada, humor triste, atitude respeitosa. Diz haver procurado estes serviços no interesse de tratarse do hábito de alcoolizar-se (que adquiriu de três anos para cá) e de sua combalida saúde. Confessa beber demasiadamente, mas nunca haver tido alucinações terroristas (nem quaisquer outras) da vista ou da audição.

45 Caso 10 - Baltazar. Ficha de observação de B.R.P. CJM, caixa 26, ano de 1938. Acervo IMASJM/SMS-RJ.

46 Caso 24 - Euclides. Ficha de observação de E.G.O. CJM, caixa 43, ano de 1942. Acervo IMASJM/SMS-RJ. 
Tampouco apresenta o tremor da língua e o sinal de Quinquand. Somente sente, além de umas tonteiras (nas manhãs seguintes às grandes libações) uma invencível anorexia, com penoso mal-estar e adinamia. Não conseguindo poder trabalhar assim, nem vencer o hábito de beber, procurou tratar-se aqui. (...) Teve bom aproveitamento no Instituto, onde aprendeu o ofício. Saiu aos 13 anos para empregar-se e poder ajudar a mãe (...) desde essa época, [tem] trabalhado sem intervalos. (...) Deseja ocupar-se em qualquer serviço compatível com o seu estado de saúde atual. Sabe entalhar em madeira e desenha regularmente. Fez, a nosso pedido, o desenho de uma margarida, desenho que anexamos a esta observação. (...) Devido ao seu talento de entalhar madeira, Eliomar faz um quadro e na visita feita por Getúlio Vargas à Colônia, o presenteia com o quadro, em 1939.47

Morreu em 1940 de profunda anemia. Ao longo dos três anos que viveu na colônia, fez praxiterapia em limpeza e carpintaria, infelizmente não foi um interno do grupo que teve alta em pouco tempo.

\section{Histórias de internos e suas condições de trabalho}

PASSAREMOS A APRESENTAR histórias que relacionavam o adoecimento por doença mental com condições relativas ao trabalho. Neste grupo se insere Antônio, 18 anos, lavrador, branco, oriundo do estado do Rio de Janeiro, que fora internado em 13/10/1942, tendo recebido alta experimental em 18/02/1943, por estar passando bem e calmo, da qual não retornou. A mãe foi a requerente da internação e contou ao médico que o filho:

(...) trabalhava sem grandes alterações, quando começou a se exceder, trabalhando exageradamente, dobrando tarefas, "a fim de comprar uma carroça". Esforçara-se assim quando foi preso de forte febre e dor nos pulmões (...). Logo, sobreveio grande excitação motora, traduzindo assim certa euforia e logorreia, para dar lugar, algum tempo depois, [a] um estado confusional permanente. Nesta ocasião tentou matar um irmãozinho. ${ }^{48}$

Antônio foi diagnosticado na CJM como um caso de psicose autotóxica (confusão mental), sem nenhuma referência do médico ao seu estado de exaustão decorrente do excesso de trabalho, apenas referiu-se ao descrever os dados de sua constituição física que o mesmo pesava $38 \mathrm{~kg}$. Em seu tratamento recebeu, entre outras medicações, cápsulas fortificantes.

Um outro caso cujo adoecimento foi atribuído pelo interno às péssimas condições de trabalho (grande variação de temperatura, trabalho estafante...) é o de Afrânio, 35 anos, casado, foguista, pardo, natural de Ouro Preto/MG. Ingressou em 19/03/1944, recebeu alta a pedido da família e teve evasões curtas, sempre retornando, vindo a falecer em 1951, aos 42 anos, sem ter a causa explicitada na documentação. Ao longo da sua primeira consulta, o médico relata que o paciente "conta que na $5^{\mathrm{a}}$ feira à noite, havendo bebido um pouquinho, ficou desatinado e foi detido. Apresenta tremor na língua e dedos, [relata ser] foguista e músico, dizendo por fim

47 Caso 21 - Eliomar. Ficha de observação de E.T.Q. CJM, caixa 23, 1937. Acervo IMASJM/SMS-RJ

48 Caso 1 - Antônio. Ficha de observação de A.C. CJM, caixa 42, ano 1942. Acervo IMASJM/SMS-RJ. 
que por causa dessas funções, bebe quando trabalha". Inicialmente foi diagnosticado como psicótico heterotóxico e alcoolista crônico. Em consulta realizada em 1945, Afrânio referiu sentir perturbações auditivas e visuais "vendo fumaças e sentindo cheiros esquisitos". Lembrando a profissão do mesmo, foguista, aquele encarregado das fornalhas nas máquinas a vapor, tais perturbações nos parecem compreensíveis face às suas condições de trabalho. ${ }^{49}$

Cândido, 43 anos, branco, casado, tintureiro, nascido em Valença/RJ, foi internado na CJM em 21/11/1941 e recebeu uma licença experimental, a pedido da família, em dezembro do mesmo ano, da qual não retornou. Durante sua consulta, declarou ao médico ter combinado com a mãe de buscar ajuda em algum hospital da capital, pois estava sofrendo de insônia. $O$ mesmo "desconfia ter sido afetado pelas tintas. É morigerado e cumpridor de seus deveres. Ultimamente vinha trabalhando demais. Nega ter tonteiras e ataques". ${ }^{50}$ Recebeu como diagnóstico psicose heterotóxica, confirmando a suspeita do mesmo de ter sido intoxicado pelas tintas.

Olegário, 35 anos, casado, branco, marítimo, pernambucano. Ingressou trazido pela família em agosto de 1934 e oito meses depois recebeu alta. Foi diagnosticado com paralisia.

No começo do mês de novembro de 1933, estava sua mulher muito mal, desenganada mesmo pelos médicos, recebeu ao mesmo tempo ordem para embarcar. Para não perder o emprego, viu-se obrigado a partir, o que o fez bastante preocupado. (...) Ao chegar no ponto final do itinerário do navio em que trabalhava (Aracaju), desenvolveu-se nele um delírio persecutório, associado a uma grande excitação psicomotora (...). Em consequência disto, foi fechado em uma cabine para ser trazido de volta para o Rio de Janeiro. Mas ao chegar no porto de S. Salvador, na Bahia, saiu da cabine, não sabendo como, a dizer que havia uma bomba a bordo e para fugir à catástrofe atirou-se no mar. Após ter permanecido durante uma hora e meia dentro d'água, foi retirado e enviado para a terra, sendo então remetido para o hospital da capital baiana. (...) Na Bahia foi-lhe feito o exame de sangue dando o Wasserman fortemente positivo, segundo informação da família. A família, ao saber disso, mandou buscá-lo e consultaram um médico que lhe receitou um calmante e injeção de bismuto. (...) Aconselhada a família para procurar-nos, assim o fizeram; uma vez aqui, foi-nos entregue o mesmo. ${ }^{51}$

Essa história de Olegário começa de uma maneira revoltante pelo fato do mesmo ter que viajar mesmo com a esposa muito mal de saúde; e o "enlouquecimento" dele não foi relacionado com essa imensa pressão de escolher ficar com a esposa ou não perder o emprego, mas sim à sífilis, doença que na época atingia a muitos brasileiros..$^{52}$ Toda sua história de ter começado a trabalhar como dispenseiro e ter crescido por mérito na profissão, que consta também na sua documentação como fala da família, nos parece ter sido apagada.

A história de vida de Murilo foi dentro da CJM dos seus 24 anos até sua morte aos 52 anos, de enterocolite, bronquite e enfisema: mais de 28 anos internado, com algumas

49 Caso 8 - Afrânio. Ficha de observação de A.F.S. CJM, caixa 58, ano 1944. Acervo IMASJM/SMS-RJ.

50 Caso 11 - Cândido. Ficha de observação de C.T.S. CJM, caixa 39, ano 1941. Acervo IMASJM/SMS-RJ.

51 Caso 53 - Osvaldo. Ficha de observação de O.M.D. CJM, caixa 16, ano de 1934. Acervo IMASJM/SM-RJ.

52 Lembrar das considerações feitas com relação ao amplo número de casos de internos que apresentavam sífilis, que foi abordado na primeira parte do artigo, tendo como referência a obra de Sérgio Carrara, nota 24. 
evasões com retorno, que somadas dariam o tempo de três anos, aproximadamente. Murilo era branco, solteiro, nascido na capital e era ourives; foi internado na CJM em 1937. Na sua primeira consulta na CJM, afirmou que "era ourives, mas [que] abandonou a profissão havia três para quatro anos, estando sem trabalho. Informa que deixou de trabalhar "porque estava com fraqueza nos rins'". ${ }^{53}$ Segundo o médico, ele nega ter alucinações auditivas, mas, "contudo, parece sofrê-las de caráter imperativo: olha às vezes de lado como que escutando alguma coisa e imediatamente levanta-se, tentando sair, sem pedir licença (...). ${ }^{54}$ Recebeu o diagnóstico de esquizofrenia. Segundo as informações na sua documentação, não dormiu nas primeiras noites, tentando fugir. Tinha aspecto doentio com um olhar inexpressivo, mas ao mesmo tempo fixado na escrita do médico.

Em outra consulta, realizada em 1942, permanecia bastante emagrecido e, segundo o médico, apresentava dissociação de ideias e tinha o ar distante, como se nada o interessasse: "está constantemente perdido num mundo de devaneios, de sonhos e fantasias". ${ }^{55}$ De acordo com as observações do médico, tinha pensamento pré-lógico, obedecendo a leis mágicas que se exteriorizam por representações simbólicas e "nenhum desejo de mudar a situação, prefe[rindo] que as coisas aconteçam sem que sua vontade interfira no curso das ocorrências". ${ }^{56}$

Além de, ao trabalhar com ouro, de fato ou não, Ihe ter causado algum tipo de toxidade no seu organismo, alguma doença nos rins, nos impressionou bastante o estado psíquico e emocional do interno e sua opção por viver sua própria realidade, segundo suas 'leis mágicas', 'sonhos', 'fantasias', opção que para o médico tivera o significado de não ter "nenhum desejo de mudar a situação". Nessa longa vida dentro da CJM, não foi encaminhado para nenhuma atividade de praxiterapia (trabalhar na lavoura, na jardinagem ou em outras atividades existentes para os internos). Evadiu-se diversas vezes, mas mesmo assim, na opinião do médico, o interno seguia, como sempre, tomado pelas suas 'ruminações', maneira pela qual o médico denominava os sonhos e fantasias de Murilo.

\section{Considerações Finais}

TAL COMO MURILO, com os sonhos e fantasias, muitos dos internos por nós analisados que foram internados por questões relativas aos mundos do trabalho, encontraram uma instituição cuja proposta principal era a praxiterapia como forma de cura ou ao menos de socialização; e a moradia heterofamiliar, com famílias de funcionários, também como forma de melhor socialização e qualidade de vida, mas que na realidade atingia a muito poucos internos. Desse grupo de 62 pessoas, apenas 12 internos foram indicados para a praxiterapia e em nenhuma das documentações vimos qualquer indicação à moradia heterofamiliar.

53 Caso 47 - Murilo. Ficha de observação de M.P.C. CJM, caixa 24, ano 1937. Acervo IMASJM/SMS-RJ.

54 Ibidem.

55 Ibidem.

56 Ibidem. 
No gráfico das causas dos falecimentos, o grande número de fichas sem a informação nos levou a pensar se ao menos os familiares teriam sido comunicados do fato antes da documentação ser arquivada. Foram trabalhadores que adoeceram mentalmente durante as suas atividades laborativas, outros que perderam o controle frente ao desemprego, outros que se viram sem saída na vida e foram buscar por cura.

Muitos familiares estavam junto quando da internação e justificavam na maior parte das vezes que o parente não mais trabalhava e que a família não tinha como arcar com as despesas. Outros afirmavam que as crises de 'loucura' os impediam de continuar vivendo com o mesmo. Outros foram de livre e espontânea vontade acreditando que na CJM seriam curados. Muitos evadiram-se, outros receberam alta e suas histórias continuaram fora dos muros da CJM. Voltaram a trabalhar? Reencontraram suas famílias? Tiveram vidas mais felizes?

Esperamos ter atingido o nosso grande objetivo neste artigo, mostrando a riqueza do trabalho na interseção de campos da história, história da loucura e da psiquiatria e a história dos mundos do trabalho, por meio da análise de pedaços, rastros, vestígios das histórias de vida desses internos que foram viver na CJM em função dos seus universos de trabalho. Voltando a Eduardo, que abriu o título do nosso artigo, gostaríamos de partilhar com ele que também gostamos muito de olhar a lua, fixar o sol e contar as estrelas, e que isso é viver.

Recebido em 30/06/2020

Aprovado em 25/08/2020 